\title{
Greenhouse gas intensity of three main crops and implications for low-carbon agriculture in China
}

\author{
Wen Wang ${ }^{1,2}$, Yuebin $\mathrm{Lin}^{1}$, Liping Guo ${ }^{1}$, Yingchun $\mathrm{Li}^{1,2}, \mathrm{Man} \mathrm{Su}^{3}$, \\ Christian de Perthuis ${ }^{2}$, Xiaotang Ju ${ }^{4}$, Erda Lin $^{1,6}$, Dominic Moran ${ }^{5}$
}

China faces significant challenges in reconciling food security goals with the objective of becoming a low-carbon economy. Agriculture accounts for approximately $11 \%$ of China's national greenhouse gas (GHG) emissions with cereal production representing a large proportion (about 32\%) of agricultural emissions. Minimizing emissions per unit of product is a policy objective and we estimated the GHG intensities (GHGI) of rice, wheat and maize production in China from 1985 to 2010. Results show significant variations of GHGls among Chinese provinces and regions. Relative to wheat and maize, GHGl of rice production is much higher owing to $\mathrm{CH} 4$ emissions, and is more closely related to yield levels. In general, the south and central has been the most carbon intensive region in rice production while the GHGI of wheat production is highest in north and northwest provinces. The southwest has been characterized by the highest maize GHGI but the lowest rice GHGI. Compared to the baseline scenario, a $2 \%$ annual reduction in $\mathrm{N}$ inputs, combined with improved water management in rice paddies, will mitigate $17 \%$ of total GHG emissions from cereal production in 2020 while sustaining the required yield increase to ensure food security. Better management practices will entail additional gains in soil organic carbon further decreasing GHGI. To realize the full mitigation potential while maximizing agriculture development, the design of appropriate policies should accommodate local conditions.

Keywords : food security, low-carbon agriculture, greenhouse gas intensity, China.

1. Institute of Environment and Sustainable Development in Agriculture, Chinese Academy of Agricultural Sciences, Beijing 100081, China

2. Climate Economics Chair, Paris-Dauphine University, Paris 75002, France

3. Graduate School of the Chinese Academy of Agricultural Sciences, Beijing 100081, China

4. College of Resources and Environmental Sciences, China Agricultural University, Beijing 100193, China

5. Land Economy and Environment Research Group, Scotland's Rural College, Edinburgh EH9 3JG, Scotland

6. Corresponding author: Erda Lin, e-mail: lined@ami.ac.cn; telephone: +8610 82105998; fax: +8610 82105998; address: Room 303, Institute of Environment and Sustainable Development in Agriculture, Chinese Academy of Agricultural Sciences, Beijing 100081, China

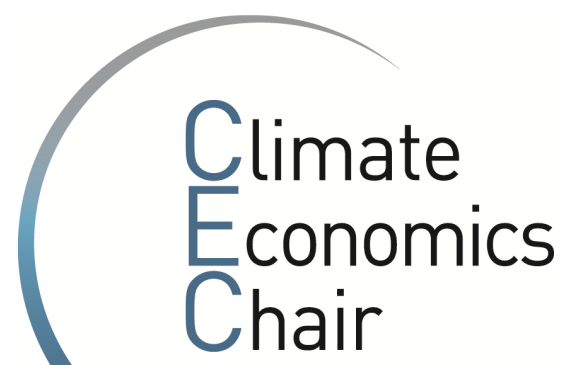

Paris-Dauphine University CDC Climat 
This page is intentionally blank - Cette page est laissée vide intentionnellement 
2 Greenhouse gas intensity of three main crops and implications for low-carbon agriculture in China

3

\section{Author names and affiliations}

5 Wen Wang ${ }^{\mathrm{a}, \mathrm{b}}$, Yuebin $\mathrm{Lin}^{\mathrm{a}}$, Liping Guo ${ }^{\mathrm{a}}$, Yingchun $\mathrm{Li}^{\mathrm{a}}$, Man $\mathrm{Su}^{\mathrm{c}}$, Christian de Perthuis ${ }^{\mathrm{b}}$, Xiaotang Ju ${ }^{\mathrm{d}}$, 6 Erda Lin ${ }^{\mathrm{a}, *}$, Dominic Moran ${ }^{\mathrm{e}}$

$7 \quad{ }^{a}$ Institute of Environment and Sustainable Development in Agriculture, Chinese Academy of 8 Agricultural Sciences, Beijing 100081, China, ${ }^{\mathrm{b}}$ Climate Economics Chair, Paris-Dauphine University, 9 Paris 75002, France, ${ }^{\mathrm{c}}$ Graduate School of the Chinese Academy of Agricultural Sciences, Beijing 10 100081, China, ${ }^{\mathrm{d}}$ College of Resources and Environmental Sciences, China Agricultural University, 11 Beijing 100193, China, ${ }^{\mathrm{e}}$ Land Economy and Environment Research Group, Scotland's Rural College, 12 Edinburgh EH9 3JG, Scotland.

13 *Corresponding author: Erda Lin, e-mail: lined@ami.ac.cn; telephone: +8610 82105998; fax: +8610 14 82105998; address: Room 303, Institute of Environment and Sustainable Development in Agriculture, 15 Chinese Academy of Agricultural Sciences, Beijing 100081, China. 


\section{Abstract:}

China faces significant challenges in reconciling food security goals with the objective of becoming a low-carbon economy. Agriculture accounts for approximately $11 \%$ of China's national greenhouse gas (GHG) emissions with cereal production representing a large proportion (about 32\%) of agricultural emissions. Minimizing emissions per unit of product is a policy objective and we estimated the GHG intensities (GHGI) of rice, wheat and maize production in China from 1985 to 2010. Results show significant variations of GHGIs among Chinese provinces and regions. Relative to wheat and maize, GHGI of rice production is much higher owing to $\mathrm{CH}_{4}$ emissions, and is more closely related to yield levels. In general, the south and central has been the most carbon intensive region in rice production while the GHGI of wheat production is highest in north and northwest provinces. The southwest has been characterized by the highest maize GHGI but the lowest rice GHGI. Compared to the baseline scenario, a $2 \%$ annual reduction in $\mathrm{N}$ inputs, combined with improved water management in rice paddies, will mitigate $17 \%$ of total GHG emissions from cereal production in 2020 while sustaining the required yield increase to ensure food security. Better management practices will entail additional gains in soil organic carbon further decreasing GHGI. To realize the full mitigation potential while maximizing agriculture development, the design of appropriate policies should accommodate local conditions.

Key words: food security, low-carbon agriculture, greenhouse gas intensity, China 


\section{Research highlights}

Greenhouse gas intensity (GHGI) of rice, wheat and maize production are estimated on provincial,

37 regional and national scales in China

Substantial variation in GHGI of cereal production exists among provinces and regions

39 Reducing GHG emissions, ensuring food security and improving soil fertility can be achieved

40 simultaneously

41 GHGI of cereal production stabilized or decreased after 2005 and should further decline to ensure the successful transition towards low-carbon agriculture 


\section{Introduction}

China has made substantial efforts to increase crop production to feed about $20 \%$ of the global population with only 8\% of the world's arable land (World Bank 2013). From 1961 to 2010, total cereal production has increased almost five-fold from 107 to 497 million tons (Mt) and crop yields have improved at almost the same pace (FAO 2013). Looking towards 2020, the government set a target of increasing national grain production capacity to over $545 \mathrm{Mt}$ to meet growing demands for higher animal protein diets and to maintain the domestic food self-sufficiency rate at 95\% (NDRC 2009). This implies that while constrained by limited arable land, grain yield must grow by at least $0.9 \%$ annually in the period 2011-2020. While facing this food security challenge China is also grappling with related constraints in terms of declining water availability, an increasing opportunity cost of rural labour and the challenges of climate change. The latter has emerged as a significant threat to agricultural production, altering weather conditions and causing more frequent extreme weather events and disasters (IPCC 2007a).

While vulnerable to climate change agriculture is also a significant source of anthropogenic greenhouse gases (GHG) emissions (IPCC 2007b). The sector emitted approximately $820 \mathrm{Mt} \mathrm{CO}_{2}$ equivalent $\left(\mathrm{CO}_{2} \mathrm{e}\right)$ in 2005 , or $11 \%$ of the national total (NCCC 2012). Agriculture was the largest source of nitrous oxide $\left(\mathrm{N}_{2} \mathrm{O}\right)$ and methane $\left(\mathrm{CH}_{4}\right)$ emissions, arising mainly from livestock enteric fermentation, Nitrogen (N) additions to cropland, rice cultivation and animal waste management. Cropland $\mathrm{N}_{2} \mathrm{O}$ emissions produced in soils through the microbial processes of nitrification and denitrification was responsible for $25 \%$ of agriculture $\mathrm{GHG}$ emissions in 2005 and $\mathrm{CH}_{4}$ emissions from rice cultivation contributed $20 \%$. Cereal production (rice, wheat and maize) accounted for about $47 \%$ of national $\mathrm{N}$ fertilizer consumption (Heffer 2009) and generated around 32\% of GHG emissions from agriculture.

The sector is now under increasing scrutiny for its ability to mitigate climate change through both emissions reduction and carbon (C) sequestration. A range of abatement measures have been identified as applicable in the arable sector (e.g. IPCC 2007b; Oenema et al 2001; Smith et al 2008), which can be broadly grouped into increased nitrogen use efficiency (NUE), improving water regimes in rice paddies and sequestering $\mathrm{C}$ into cultivated soils. Many mitigation measures could actually be cost saving, simultaneously reducing input costs and/or enhancing productivity (Wreford et al. 2010). Further, in recent decades soil organic carbon (SOC) content of cropland has increased along with 
improved crop yields in most regions of China (Huang and Sun 2006; Pan et al. 2010; Yan et al. 2011; Yu et al. 2012) and is predicted to continue to increase in the next 40 years (Yu et al. 2013). These findings highlight the important role of cropland in achieving emission reduction, safeguarding food security and enhancing carbon sequestration.

The Chinese government has recently put more effort into combating climate change and national mitigation aspirations have been outlined in the 12th Five-Year Plan (FYP) to cut the carbon intensity of the economy by 17\% in 2015 compared with 2010 levels. The 12th FYP also called for controls on agricultural GHG emissions. In response, the Ministry of Agriculture (MOA) has initiated programs to improve fertilizer use efficiency by $3 \%$ and enhance irrigation water use efficiency by $6 \%$ by 2015 from 2010. In addition, the government has planned to bring an additional 11.3 Mha of croplands under conservation tillage between 2009-2015 in north China (MOA 2009). The growing desire to integrate climate change dimensions into agricultural policies reflects the government's willingness to pursue low carbon development in agriculture, characterized by higher productivity, more efficient use of resources and low GHG emissions intensity (Norse 2012).

The concept of GHG intensity (GHGI), expressed as the overall GHG emissions per unit of product, is suggested as a useful metric to evaluate NUE and to help identify mitigation strategies (Chen et al. 2011; Venterea et al. 2011; Tubiello et al. 2012). Applying such an indicator can encourage better management practices resulting in higher crop production per area and reduced $\mathrm{N}$ losses and GHG emissions (van Groenigen et al. 2010).

In this context, the Global Research Alliance on Agricultural Greenhouse Gases was launched in December 2009 to help reduce the GHGI of agricultural production. FAO (Tubiello et al. 2014) reported that over the period 1961-2010 the world average GHGI of rice decreased by 49\% while that of main cereals (wheat and maize) increased by $45 \%$, and suggested that effective mitigation strategies are needed to achieve sustainable intensification, ensuring that further efficiency improvements can lead to reduced absolute emissions. Bonesmo et al. (2012) investigated the GHGI of 95 arable farms in Norway and suggested that increased gross margins in grain and oilseed crop production could be achieved with decreasing GHGI. The GHGI of cereal production on experimental sites was also quantified to compare the overall mitigation effects of different abatement measures. Findings (e.g. Mosier et al. 2006; Shang et al. 2011; Huang et al. 2013; Ma et al. 2013) indicated that economic and climate benefits can be simultaneously achieved by improved management practices. But to date there 
104 is no synthetic estimate of current and historical GHGI of cereal production on a national, regional or

105 provincial level in China. Such information is crucial for identifying efficient regional mitigation

106 strategies and actions tailored to local agricultural production systems and management practices.

107 This paper provides estimates of GHGI for rice, wheat and maize production using agro-statistics

108 data for the national, regional and provincial scale for 2006. To illustrate the trends and the evolution

109 of intensity we quantity national and regional GHGI from 1985 to 2010 at 5-year intervals and analyze

110 emission reduction and carbon sequestration potentials from cereal production. The aim is to provide

111 suggestions on possible national or regional policies to foster sustainable intensification in rural China.

112 The paper is structured as follows. Section two describes the derivation of GHGI and outlines data

113 sources for projecting intensities. Section three discusses the results before a conclusion in section

114 four. 


\section{Materials and methods}

\subsection{Methodology}

GHGI refers to the climatic impacts of agriculture practices in terms of per unit of product and is calculated by dividing total Global Warming Potential (GWP)-weighted emissions of cereal production by crop yield. $\mathrm{N}_{2} \mathrm{O}$ emissions are accounted for quantifying GHGI of wheat and maize production while both $\mathrm{CH}_{4}$ and $\mathrm{N}_{2} \mathrm{O}$ are considered for rice paddies. Carbon sequestration is not directly included in the estimate of GWP-weighted emissions due to large uncertainties in SOC content and limited data availability. Despite consensus on the average SOC increment in China's cropland, discrepancies in annual intensity change rates have been reported using various methods (Huang and Sun 2006; Sun et al. 2010 ; Pan et al. 2010; Yan et al. 2011; Yu et al. 2012). In addition, SOC density change data at the provincial level is unavailable. Nevertheless, SOC change patterns and interactions with GHGI will be analyzed in the discussion section. The analysis focuses on emissions within the farm gate, i.e. they are not full life-cycle assessment (e.g. emissions related to energy use and fertilizer manufacture and transportation).

We followed the 2006 IPCC Guidelines for National Greenhouse Gas Inventories (IPCC, 2006) to estimate $\mathrm{N}_{2} \mathrm{O}$ emissions from rice, wheat and maize production (Eqn ( $\mathrm{S} 1$ )). We considered direct $\mathrm{N}_{2} \mathrm{O}$ emissions from the three major $\mathrm{N}$ input sources - synthetic fertilizers, organic manure and crop residues. Due to high uncertainty and relatively minor contribution, indirect $\mathrm{N}_{2} \mathrm{O}$ emissions via $\mathrm{N}$ deposition (associated with ammonia volatilization) and nitrate leaching and runoff were not taken into account. Quantification of $\mathrm{CH}_{4}$ emissions from rice paddies was based on regional $\mathrm{CH}_{4}$ flux from comprehensive studies conducted by Zhang et al. (2011a).

$$
G H G I=\frac{\text { Emissions }_{\mathrm{N}_{2} \mathrm{O}}+\text { Emissions }_{\mathrm{CH} 4(\mathrm{FR})}}{\text { Yield }}
$$

$$
\begin{aligned}
& \text { Emissions }_{N_{2} \mathrm{O}}=N_{2} \mathrm{O}-N_{\text {input }} \llbracket E F_{l(F R)}\left[44 / 28 \llbracket \mathrm{GWP}_{2} \mathrm{O}\right. \\
& \text { Emissions }_{C \mathrm{H}_{4}(F R)}=\text { Flux }_{C \mathrm{CH}_{4}(F R)}\left[\mathrm{GWP}_{\mathrm{CH}_{4}}\right. \\
& \mathrm{N}_{2} \mathrm{O}-N_{\text {input }}=F_{S N}+F_{A W}+F_{C R}
\end{aligned}
$$

GHGI is the GHG intensity of crop production $\left(\mathrm{kgCO}_{2} \mathrm{e} / \mathrm{t}\right)$. Emissions $\mathrm{N} 2 \mathrm{O}_{\mathrm{O}}$ is the per hectare $\mathrm{N}_{2} \mathrm{O}$ emissions from rice, wheat or maize fields $\left(\mathrm{kgCO}_{2} \mathrm{e} / \mathrm{ha}\right)$. Emissions $\mathrm{CH}_{\mathrm{CHR})}$ is the per hectare $\mathrm{CH}_{4}$ emissions from rice paddies $\left(\mathrm{kgCO}_{2} \mathrm{e} / \mathrm{ha}\right)$. Yield denotes the per hectare average production (t/ha). $\mathrm{N}_{2} \mathrm{O}-\mathrm{N}_{\text {input }}$ represents the per hectare total $\mathrm{N}$ inputs $(\mathrm{kgN} / \mathrm{ha}) . \mathrm{EF}_{1}$ and $\mathrm{EF}_{1(\mathrm{FR})}$ are the emission factors 
141

142

143

144

147

for $\mathrm{N}_{2} \mathrm{O}$ emissions from $\mathrm{N}$ input for uplands and rice paddies, respectively ( $\mathrm{kg} / \mathrm{kg}$ ). 44/28 is to convert emissions from $\mathrm{kg} \mathrm{N}_{2} \mathrm{O}-\mathrm{N}$ to $\mathrm{kg} \mathrm{N}_{2} \mathrm{O}$. Flux $\mathrm{CH}_{4(\mathrm{FR})}$ represents the $\mathrm{CH}_{4}$ flux from rice paddies $\left(\mathrm{kgCH}_{4} / \mathrm{ha}\right)$. $\mathrm{GWP}_{\mathrm{N} 2 \mathrm{O}}$ and $\mathrm{GWP}_{\mathrm{CH} 4}$ denote the direct GWP of $\mathrm{N}_{2} \mathrm{O}$ and $\mathrm{CH}_{4}$ respectively at the 100yr horizon, 298 and 25. $\mathrm{F}_{\mathrm{SN}}, \mathrm{F}_{\mathrm{AW}}, \mathrm{F}_{\mathrm{CR}}$ represent per hectare $\mathrm{N}$ input from synthetic fertilizers, animal manure and crop residues, respectively ( $\mathrm{kgN} / \mathrm{ha})$.

$$
\mathrm{F}_{\mathrm{AW}} \text { was estimated following Eqn (S2). }
$$

$$
F_{A W}=\frac{\sum_{T} N_{T}\left[\left(1-\operatorname{Frac}_{\text {Grazing(T) }}\right) \operatorname{Nex}_{T} \llbracket\left(1-\operatorname{Frac}_{\text {Loss }(T)}\right)\right.}{C A_{\text {eqv }}}
$$

$$
\begin{aligned}
& \text { Nex }=N_{\text {rate(T) }} \llbracket \frac{T A M_{T}}{1000} \llbracket 365 \\
& N_{T}=\text { Days_alive } \frac{N_{S(T)}}{365} \text { if Days_alive } T_{T}<365 \\
& C A_{\text {eqv }}=a \sqsubset C A_{\text {veg }}+b \sqsubset C A_{\text {fruit }}+C A_{\text {other }}
\end{aligned}
$$

$\mathrm{N}_{\mathrm{T}}$ is the annual population of livestock T. T denotes livestock category. $\mathrm{Frac}_{\mathrm{Grazing}(\mathrm{T})}$ is the fraction of grazing population (\%). $\mathrm{Nex}_{\mathrm{T}}$ represents the annual $\mathrm{N}$ excretion $(\mathrm{kgN} / \mathrm{animal} / \mathrm{yr})$. $\mathrm{Frac}_{\mathrm{Loss}(\mathrm{T})}$ represents the amount of managed manure $\mathrm{N}$ that is lost in the manure management system (\%). $\mathrm{CA}_{\text {eqv }}$ denotes the equivalent cropping area (kha). $\mathrm{N}_{\text {rate(T) }}$ denotes the default $\mathrm{N}$ excretion rate $(\mathrm{kgN} /(1000 \mathrm{~kg}$ animal mass/day)). $\mathrm{TAM}_{\mathrm{T}}$ is the typical animal mass $(\mathrm{kg} / \mathrm{animal})$. Days_alive $\mathrm{T}_{\mathrm{T}}$ is the average breeding days before slaughter. $\mathrm{N}_{\mathrm{S}(\mathrm{T})}$ is the average number slaughtered (or use stock number if average breeding days exceed a complete year). $\mathrm{CA}_{\mathrm{veg}}, \mathrm{CA}_{\text {fruit }}$ and $\mathrm{CA}_{\text {other }}$ are the cropping areas of vegetables, fruits and other crops (total excluding vegetable and fruits), respectively (kha). a and b is the ratio of organic manure received by respectively vegetable fields and fruits compared with other crop lands. $\mathrm{F}_{\mathrm{CR}}$ was estimated following Eqn (S3).

$$
F_{C R}=\frac{\sum_{i} F_{C R-A G(i)}+F_{C R-B G(i)}}{\sum_{i} C A_{i}}
$$

$$
=\frac{\sum_{i} P d t_{i} \square R_{S T-G R(i)} \square N_{i} \square\left(R_{S R(i)}+R_{B G-A G(i)}\right)}{\sum_{i} C A_{i}}
$$

$\mathrm{F}_{\mathrm{CR}-\mathrm{AG}(\mathrm{i})}$ and $\mathrm{F}_{\mathrm{CR}-\mathrm{BG}(\mathrm{i})}$ represent the $\mathrm{N}$ input from aboveground and belowground crop residues, respectively ( $\mathrm{kgN} / \mathrm{ha}$ ). i denotes crop type (rice, wheat, maize). $\mathrm{CA}_{\mathrm{i}}$ is the annual cropping area (kha). $\mathrm{Pdt}_{\mathrm{i}}$ is the annual harvested product (kt). $\mathrm{R}_{\mathrm{ST}-\mathrm{GR}(\mathrm{i})}$ is the ratio of straw to grain in terms of dry matter. $\mathrm{N}_{\mathrm{i}}$ 
162

163

is the $\mathrm{N}$ content of crop i residue $(\mathrm{g} / \mathrm{kg}) . \mathrm{R}_{\mathrm{SR}(\mathrm{i})}$ is the proportion of above-ground residue returned to land (\%). $\mathrm{R}_{\mathrm{BG}-\mathrm{AG}(\mathrm{i})}$ is the ratio of below-ground residue weight to above-ground plant weight.

Since N application rates for the three main cereals are only available for 2005 and 2010 at 5-year intervals, Eqn (S4) was formulated to estimate the $\mathrm{N}$ application rate in a given year.

$$
F_{S N(i) j}=F_{S N(i) 2005} \cdot \frac{F_{S N j}}{F_{S N 2005}}=F_{S N(i) 2005} \bullet \frac{T N_{j}}{T C A_{j}} \cdot \frac{T C A_{2005}}{T N_{2005}}
$$

$\mathrm{F}_{\mathrm{SN}(\mathrm{ijj})}$ is the $\mathrm{N}$ application rate in year $\mathrm{j}$ in a province $(\mathrm{kgN} / \mathrm{ha})$. i denotes crop type (rice, wheat, maize) and $\mathrm{j}$ denotes year. $\mathrm{F}_{\mathrm{SN}(\mathrm{i}) 2005}$ is the $\mathrm{N}$ rate of crop i in $2005(\mathrm{kgN} / \mathrm{ha}) . \mathrm{F}_{\mathrm{SNj}}$ and $\mathrm{F}_{\mathrm{SN} 2005}$ denote the crop-wide average $\mathrm{N}$ rate in year $\mathrm{j}$ and 2005 , respectively $(\mathrm{kgN} / \mathrm{ha}) . \mathrm{TN}_{\mathrm{j}}$ and $\mathrm{TN}_{2005}$ are the provincial total synthetic $\mathrm{N}$ consumption in year $\mathrm{j}$ and $2005(\mathrm{kt}) . \mathrm{TCA}_{\mathrm{j}}$ and $\mathrm{TCA}_{2005}$ represent the total cropping area in year $\mathrm{j}$ and $2005(\mathrm{kha})$.

\subsection{Data sources and treatment}

We used the three-year average of 2005-2007 to represent 2006 conditions to avoid large interannual variations in the dataset. Agriculture activity data (cropping area, production, yield, total $\mathrm{N}$ fertilizer consumption and livestock number) were extracted from the China Rural Statistical Yearbooks (MOA 1986-2013) and the China Livestock Yearbooks (MOA 2001-2011). Per hectare N application rates for individual crops were collected from the China Agricultural Products Cost-Benefit Yearbooks (NDRC 1998-2011), and we adopted $\mathrm{N}$ fraction of $30 \%$ in the reported compound and mixed fertilizers (Sun and Huang, 2012). China-specific emission factors for direct $\mathrm{N}_{2} \mathrm{O}$ emissions from croplands were obtained from studies by Gao et al. (2011), which are 0.0105 and 0.0041 for upland fields and rice paddies, respectively. $\mathrm{CH}_{4}$ fluxes of rice paddies were direct $\mathrm{CH} 4 \mathrm{MOD}$ modeled results from studies by Zhang et al. (2011a), which were employed for compiling National GHG Emission Inventories. The annual number of livestock slaughtered was collected for pigs, hens, broiler chicken and rabbits with the average breeding days standing at 158,65, 352 and 105, respectively (MOA 2001-2011). For other types of animals, annual stock numbers were used. The fraction of grazing cattle or sheep was the ratio of total grazing animals (the sum of livestock numbers in grazing areas and half-grazing areas) to the total stock number (MOA 2001-2011). a and b in Eqn (S2)were assigned 4 and 5 since survey results (Huang and Tang 2010; Zhang et al. 2013) reported that vegetable and fruit fields generally received respectively 4 and 5 times more organic manure than cereal cropping lands in 
the 2000s.

Other information required in Eqn (S2) was selected from relevant literature and IPCC default values corresponding to conditions in China as displayed in Table 1a. Values for parameters in Eqn (S3) were mainly obtained from the research by Gao et al. (2011) and are summarized in Table 1b. The proportion of above-ground straw residues returned to land in 2006 was derived from results report by Gao et al. (2009). The nationwide ratio of straw retuned to land was reported at $15.2 \%$ in 1999 (Han et al. 2002) and rose to $24.3 \%$ in 2006 (Gao et al. 2009), implying an annual rate of increase of $6.93 \%$.

This rate was employed to estimate the percentage of straw recycled to farmland in target years.

Table 1a Selected values for estimating $\mathrm{N}$ input to croplands from animal manure

\begin{tabular}{llllllllll}
\hline & $\begin{array}{l}\text { Non-dairy } \\
\text { cattle }\end{array}$ & $\begin{array}{l}\text { Milk } \\
\text { cows }\end{array}$ & $\begin{array}{l}\text { Sheep } \\
\text { (goats) }\end{array}$ & Horses & Asses & Mules & Pigs & Chicken Rabbits \\
\hline Frac $_{\text {Grazing }}$ a & $17 \%$ & & $35 \%$ & & & & & & \\
$\mathrm{~N}_{\text {rate }}$ & 0.34 & 0.47 & 1.27 & 0.46 & 0.46 & 0.46 & 0.50 & 0.82 & \\
$\mathrm{TAM}$ & 319 & 350 & 29 & 238 & 130 & 130 & $50^{\mathrm{b}}$ & 2 & \\
$\mathrm{Nex}$ & 39.6 & 60.0 & 13.4 & 40.0 & 21.8 & 21.8 & 9.1 & 0.5 & 8.1 \\
Frac $_{\text {Loss }}$ & $40 \%$ & $40 \%$ & $67 \%$ & $50 \%$ & $50 \%$ & $50 \%$ & $35 \%$ & $50 \%$ & $50 \%$ \\
Days_alive $^{c}$ & & & & & & & 158 & 180 & 105 \\
\hline
\end{tabular}

${ }^{\mathrm{a}}$ Data in this table represents the national average.

${ }^{\mathrm{b}}$ IPCC default value for Asia is 28. Here we adopted 50 according to Chinese conditions.

${ }^{\mathrm{c}}$ Days_alive of chicken is the weighted number of broiler chicken (65 days) and hens (352 days), which account for $60 \%$ and $40 \%$ of chicken population, respectively.

Table $1 \mathrm{~b}$ Selected values for estimating $\mathrm{N}$ input to croplands from crop residues

\begin{tabular}{llccc}
\hline & & Rice & Wheat & Maize \\
\hline $\mathrm{R}_{\text {ST-GR }}$ & & 0.9 & 1.1 & 1.2 \\
$\mathrm{~N}$ & $\mathrm{~g} / \mathrm{kg}$ & 9.1 & 6.5 & 9.2 \\
$\mathrm{R}_{\mathrm{BG}-\mathrm{AG}}$ & & 0.125 & 0.166 & 0.170 \\
& North & $57.7 \%$ & $84.5 \%$ & $51.0 \%$ \\
& Northeast & $25.0 \%$ & $36.6 \%$ & $22.1 \%$ \\
& East & $19.4 \%$ & $28.5 \%$ & $17.2 \%$ \\
$\mathrm{R}_{\mathrm{SR}(2006)}$ & South Central & $58.9 \%$ & $86.3 \%$ & $52.0 \%$ \\
& Southwest & $30.1 \%$ & $44.2 \%$ & $26.6 \%$ \\
& Northwest & $14.8 \%$ & $21.6 \%$ & $13.0 \%$ \\
& National average & $29.9 \%$ & $43.8 \%$ & $26.4 \%$ \\
\hline
\end{tabular}

Note: North region includes Beijing, Tianjin, Hebei, Shanxi and Inner Mongolia; Northeast region includes Heilongjiang, Liaoning and Jilin; East region includes Shanghai, Anhui, Fujian, Jiangsu, Jiangxi, Shandong and Zhejiang; South Central region includes Guangdong, Hainan, Henan, Hubei, Hunan and Guangxi; Southwest region includes Chongqing, Guizhou, Sichuan, Yunnan and Tibet; Northwest region includes Gansu, Qinghai, Shaanxi, Ningxia and Xinjiang. 

represent 2006 levels, and historic SOC contents were derived from similar research by Yu et al.

211 (2012).

To project total GHG emissions and investigate mitigation potential from cereal production in China to 2020, we designed four agricultural management scenarios based on historical trends and the increase in expected future productivity. Total GHG emissions shall be affected by the GHGI and grain production, or $\mathrm{N}$ input and $\mathrm{CH}_{4}$ flux levels, yield and cultivated area of each crop. The annual rates of change for these factors over 2010-2020 are summarized in Table 2.

Table 2 Emission scenarios (annual rates of change) for cereal production

\begin{tabular}{|c|c|c|c|c|}
\hline Scenario & So & S1 & $\mathrm{S} 2$ & S3 \\
\hline $\mathrm{I}_{\mathrm{N} 2 \mathrm{O}}$ & Constant & $\begin{array}{l}\text { rice }-0.5 \% \\
\text { wheat }-1 \% \\
\text { maize }-1.5 \%\end{array}$ & $\begin{array}{l}\text { rice }-1.5 \% \\
\text { wheat }-2.0 \% \\
\text { maize }-2.5 \%\end{array}$ & $\begin{array}{l}\text { rice }-2.5 \% \\
\text { wheat }-3.0 \% \\
\text { maize }-3.4 \%\end{array}$ \\
\hline $\mathrm{N}_{\text {input }}$ & $\begin{array}{l}\text { rice }+0.5 \% \\
\text { wheat }+1 \% \\
\text { maize }+1.5 \%\end{array}$ & Constant & $\begin{array}{l}\text { rice }-1 \% \\
\text { wheat }-1 \% \\
\text { maize }-1 \%\end{array}$ & $\begin{array}{l}\text { rice }-2 \% \\
\text { wheat }-2 \% \\
\text { maize }-2 \%\end{array}$ \\
\hline Yield & $\begin{array}{l}\text { rice }+0.5 \% \\
\text { wheat }+1 \% \\
\text { maize }+1.5 \%\end{array}$ & Same as $\mathrm{S} 10$ & Same as $\mathrm{S} 10$ & Same as S10 \\
\hline $\mathrm{I}_{\mathrm{CH} 4}$ & $-0.5 \%$ & $-0.5 \%$ & $-0.5 \%$ & $-1.5 \%$ \\
\hline $\mathrm{CH}_{4}$ flux & Constant & Constant & Constant & $-1 \%$ \\
\hline Cropping area & Constant & Constant & Constant & Constant \\
\hline
\end{tabular}

To examine the impacts of GHGI change on overall emissions, cultivated area of each crop were assumed constant from 2010 to 2020 . In all scenarios, $0.5 \%, 1 \%$ and $1.5 \%$ annual increase in yield were assigned for rice, wheat and maize respectively, based on 2005-2013 yield data released by the MOA (2006-2013). S0 is a conservative scenario that prescribes the same proportion of increase in $\mathrm{N}$ input relative to yield improvement. Scenario $\mathrm{S} 1$ assumes that no further $\mathrm{N}$ input is required to sustain equal productivity as in $\mathrm{S} 0$, while the $\mathrm{N}$ rate decreases by $1 \%$ per year under $\mathrm{S} 2$. Scenario $\mathrm{S} 3$ is an optimal scenario incorporating best management practices to cut the overall $\mathrm{N}$ rates and improve the irrigation regimes in rice paddies while achieving the yield requirements for safeguarding national food self-sufficiency. 


\section{Results and discussions}

229

230

231

232

233

234

\subsection{GHGI of rice production in 2006}

GHGI of rice production in 2006 ranged from $730 \mathrm{kgCO}_{2} \mathrm{e} / \mathrm{t}$ in Ningxia Province to $1,549 \mathrm{kgCO}_{2} \mathrm{e} / \mathrm{t}$ in Hainan Province, with a national average of $947 \mathrm{kgCO}_{2} \mathrm{e} / \mathrm{t}$ (Fig. 1a). In general, $\mathrm{CH}_{4}$ made up about $90 \%$ of the total GHG emissions and was therefore the dominant gas in determining the carbon footprint of rice cultivation. Consequently, there was no obvious relationship between GHGI levels and $\mathrm{N}$ application rates, the latter being the major source of $\mathrm{N}_{2} \mathrm{O}$ emissions. It is, however, evident that the estimated GHGI for rice production was negatively correlated with yield levels. There was a large provincial variation in GHGI (Fig. 2a) with the most carbon intensive provinces located in the southeast coastal areas due to the highest regional $\mathrm{CH}_{4}$ flux $(250 \mathrm{~kg} / \mathrm{ha})$. The low GHGI of rice production in the southwestern provinces (Sichuan, Chongqing, Guizhou and Yunnan) can be attributed to lower $\mathrm{CH}_{4}$ flux (200 kg/ha) relative to other places $(215-250 \mathrm{~kg} / \mathrm{ha})$. Among the six major rice producing provinces, which accounted for 55\% of the national production, Hunan and Jiangxi had higher GHGIs than the national average, while Hubei, Jiangsu, Sichuan and Heilongjiang were below the national mean.

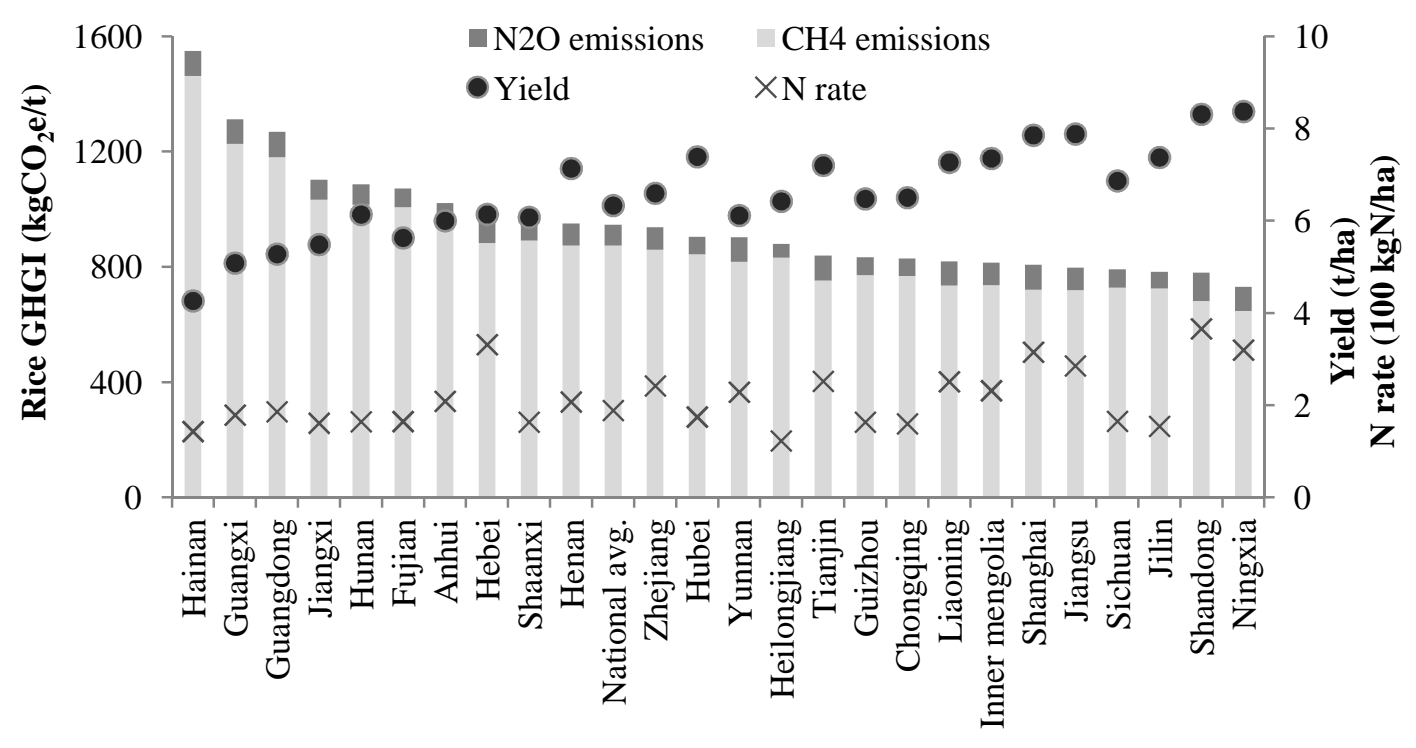

Province

(a) 

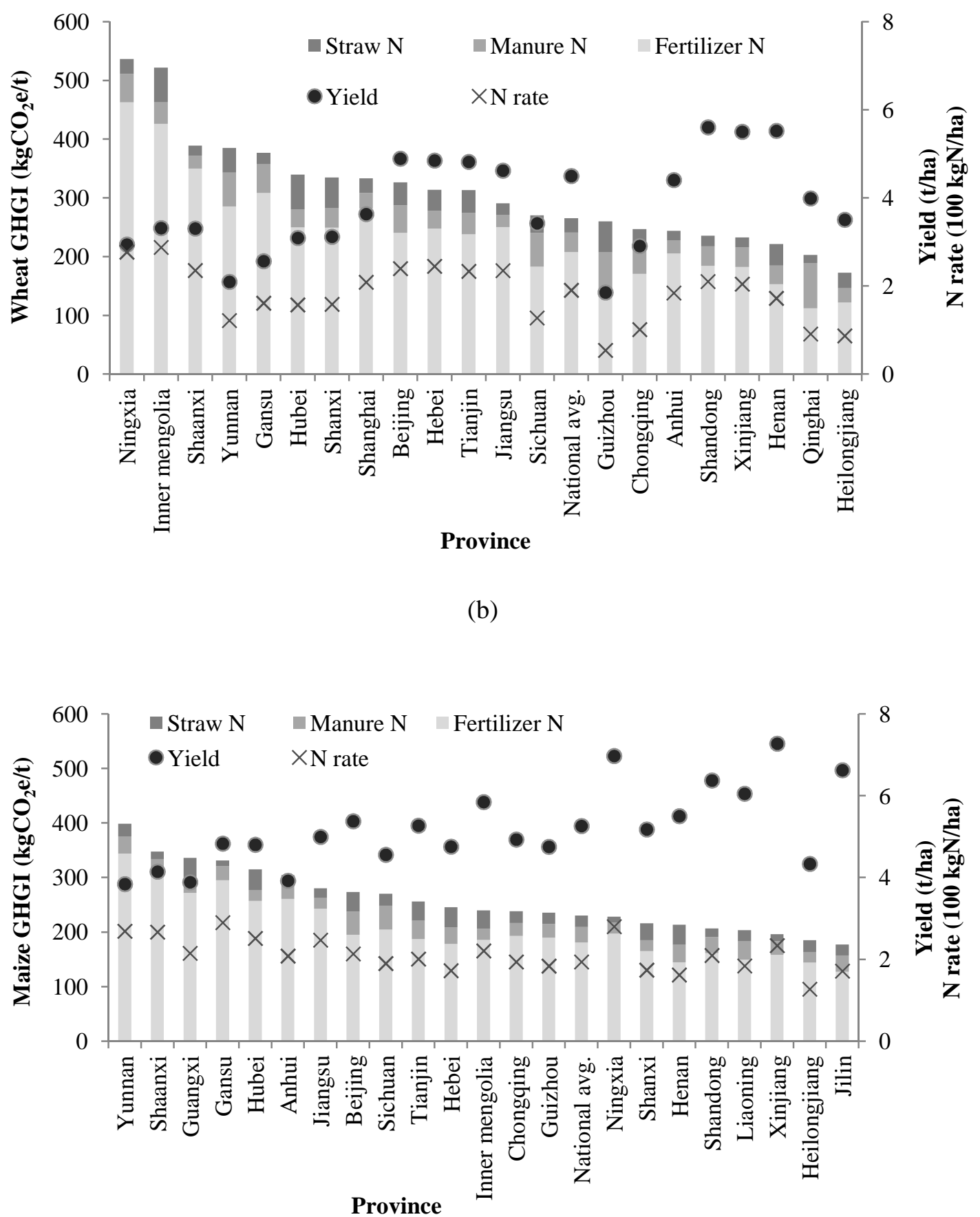

Fig.1. GHGI of rice (a), wheat (b) and maize (c) production in different provinces in 2006 


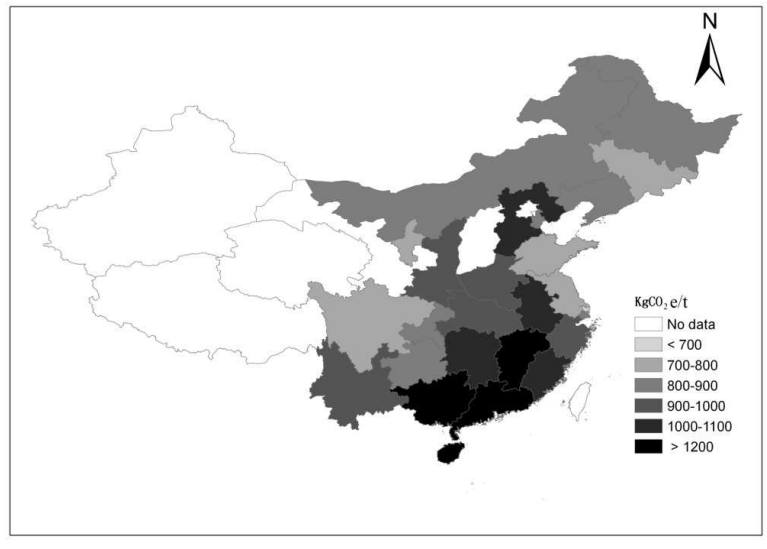

(a)

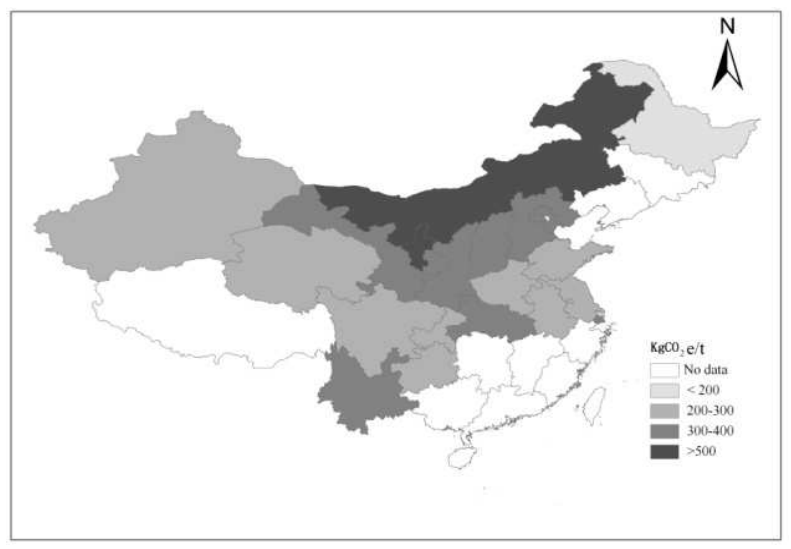

(b)

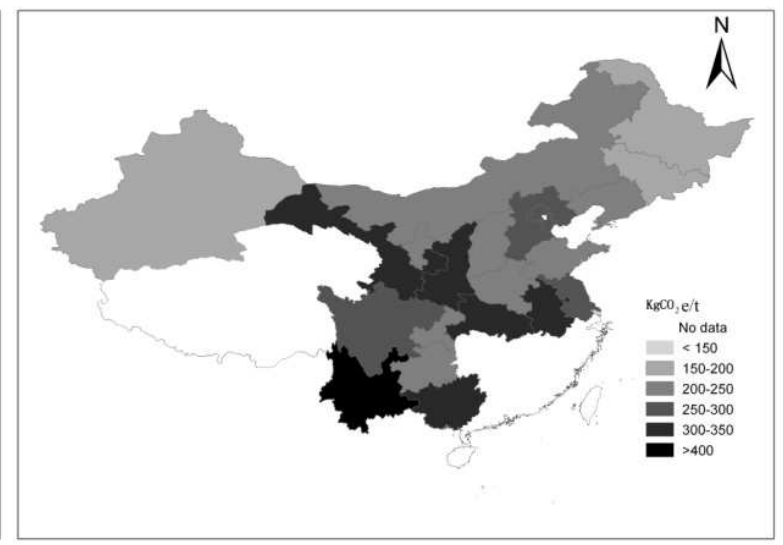

(c)

Fig.2. The provincial GHGI levels of rice (a), wheat (b) and maize (c) production for 2006

3.2. GHGI of wheat and maize production

The national average GHGI of wheat (Fig. 1b) and maize (Fig. 1b) for 2006 production were 265 $\mathrm{kgCO}_{2} \mathrm{e} / \mathrm{t}$ and $230 \mathrm{kgCO}_{2} \mathrm{e} / \mathrm{t}$, respectively. Large spatial variability can be observed among provinces. For example, producing one ton of wheat in Ningxia emitted 3 times more $\mathrm{N}_{2} \mathrm{O}$ than in Heilongjiang, attributable to significant differences in synthetic $\mathrm{N}$ input and wheat and maize yields between Chinese provinces. In general, synthetic $\mathrm{N}$ fertilizer made up at least $70 \%$ of total emissions and was therefore the primary emission contributor. Fig. 1 also shows that the trends of GHGI, which are affected by place-specific yield levels, were not necessarily consistent with those of per hectare $\mathrm{N}$ application rates. For instance, although the $\mathrm{N}$ application rate for maize in Ningxia (280 kgN/ha) was $30 \%$ higher than in Guangxi (215 kgN/ha), a much higher yield in Ningxia (6.97t/ha) than in Guangxi (3.88 t/ha) results in a lower maize GHGI in Ningxia. In contrast, a high $\mathrm{N}$ rate and low wheat productivity made Ningxia the most carbon intensive province for wheat cultivation. 
The geographic variations of GHG emissions per ton of wheat (Fig. 2b) and maize (Fig. 2c) show both similarities and differences. In general, similar levels of GHGI can be observed for wheat and maize production (except for Ningxia); e.g. Yunnan was one of the most carbon intensive areas for both wheat and maize production in 2006. The levels of maize GHGI converged to the range of 200-300 $\mathrm{kgCO}_{2} \mathrm{e} / \mathrm{t}$, with obvious correlation with $\mathrm{N}$ rates and yields. Provincial discrepancies were more evident for wheat GHGI. Among the five major wheat producing areas - Henan, Shandong, Hebei, Anhui and Jiangsu, which contributed about $73 \%$ of the national production, GHGI levels in Hebei and Jiangsu were superior to the national average. Among the major maize producing areas, only Hebei had a higher GHGI than the national mean, while Jilin, Shandong, Henan and Heilongjiang were lower.

\subsection{Implications for regional GHGI reduction strategies}

The GHGI, yield and synthetic N rate of rice, wheat and maize cultivation as well as the SOC content at the regional scale in 2006 are illustrated in Fig. 3. In general, the southwest had lowest cereal yields, albeit second highest SOC after the northeast. Conversely more $\mathrm{N}$ fertilizers were added to croplands in northwest provinces to compensate poor soil fertility, resulting in elevated regional GHGI of crop production. Fig. 3 reveals that yield levels do not necessarily correspond to local SOC status, since productivity is also influenced by climate, precipitation and other factors. In this regard, regional strategies to minimize GHGI and improve soil fertility should accommodate local climatic, soil and water conditions and management practices. For example, in the northwest measures improving SOC density (e.g. conservation tillage) should be favored to enhance soil fertility and land productivity. In intensive cropping systems in east and north China where over-fertilization is prominent, more efficient use of $\mathrm{N}$ fertilizer can allow $\mathrm{N}$ rates to be cut by 30 to $60 \%$ without sacrificing crop yields (Ju et al. 2009). Although the northeast was the least carbon intensive region in cereal production, this came at the expense of net carbon losses, especially in Heilongjiang Province (Pan et al. 2010; Yu et al. 2012), thus calling for better management practices to sustain soil fertility in this region. 
293

294

295

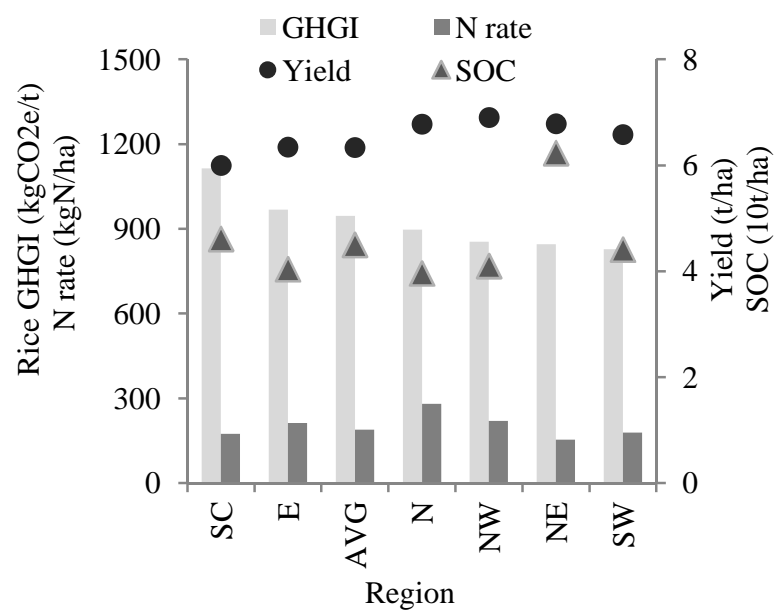

(a)

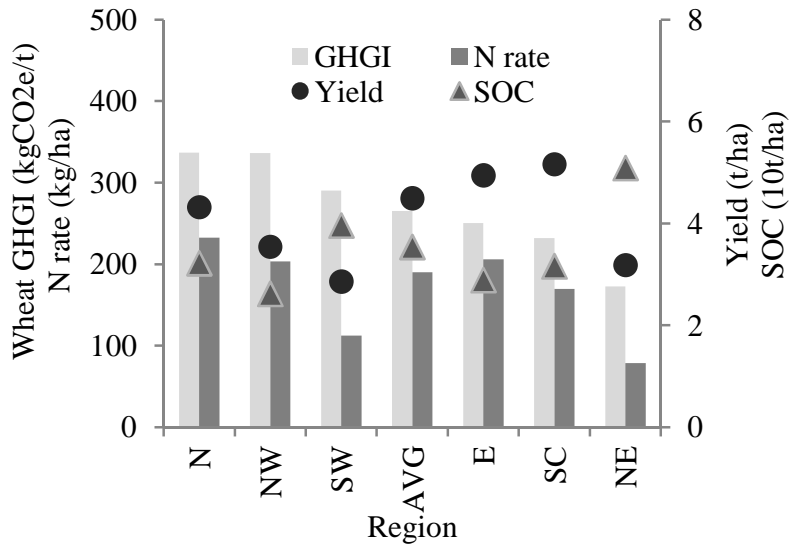

(b)

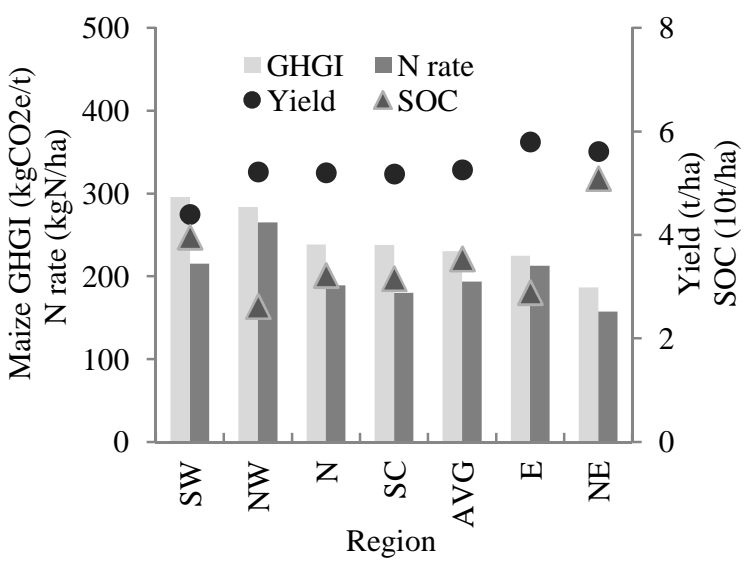

(c)

Fig.3. GHGI of rice (a), wheat (b) and maize (c) production in different regions in 2006 and its relationship with yield, N rates and SOC content. NE, N, NW, E, SC, SW and AVG refer to northeast, north, northwest, east, south and central, southwest China, and national average, respectively.

\subsection{Historical trends of regional GHGI of cereal production}

Fig. 4a shows that national GHGI of rice production evolved at a different way to those of wheat and maize production, and the latter has always been the least carbon intensive of the three crops. Rice GHGI saw little variation beween 1985 and 2000, which can be explained by nearly the same rate of growth in the $\mathrm{CH}_{4}$ flux, yield (Fig. $4 \mathrm{~b}$ ) as well as the $\mathrm{N}$ application rate over this period. However, when rice yield reached a periodic peak in 1998 the $\mathrm{CH}_{4}$ flux continued to climb, resulting in a sharp rise in GHGI in the first decade of the $21^{\text {st }}$ century. Wheat and maize GHGIs had been steadily 
increasing from 1985 to 2000 since the growth rate of $\mathrm{N}$ application exceeded the rate of yield improvement. The GHGI began to stablize or even decrease after 2000 as the combined effects of increasing yields, abeit at a lower rate, and a stabilized synthetic $\mathrm{N}$ rate promoted by the national "Soil testing and fertilizer recommendation program" (MOA 2005) initiated in 2005. At the national level, some studies (e.g. Pan et al. 2009) suggest a positive correlation between SOC improvement and cereal productivity increase (Fig. 4b).

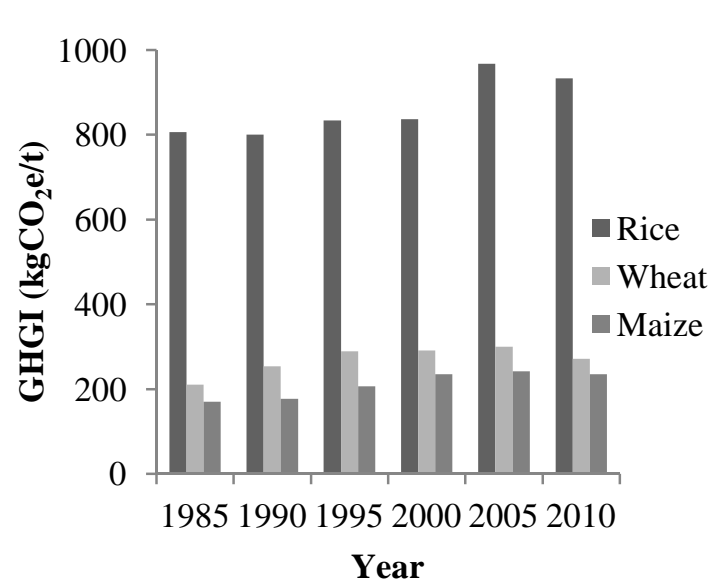

(a)

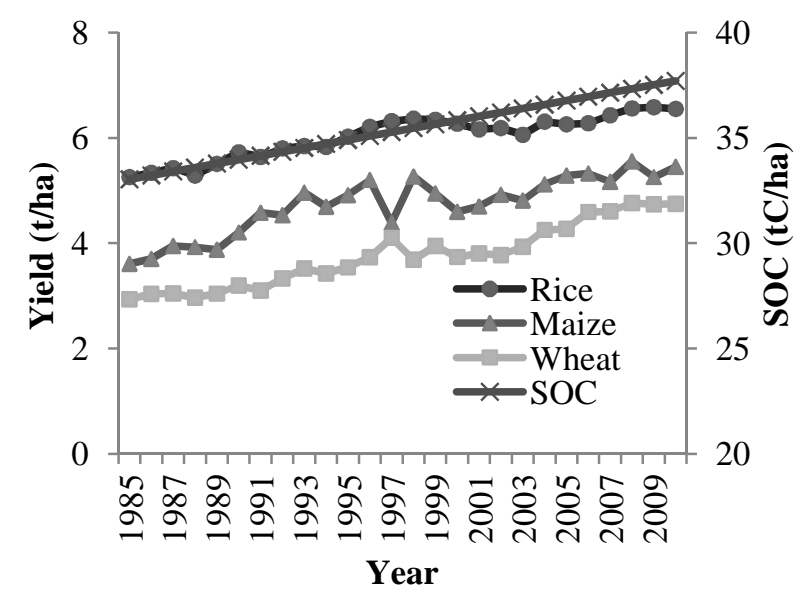

(b)

Fig.4. Historical trends of national average GHGI (a) and yield (b) of rice, wheat and maize production Fig. 5 illustrates that nearly all regional GHGI of rice(a), wheat(b) and maize(c) production reached a higher level in 2010 relative to 1985 . For rice production (Fig. 5a), south and central and east regions have consistently been the most carbon intensive areas due to high temperature and greater level of organic matter application (Zhang et al. 2011a). In parallel, rice paddies in eastern, southern and central China are found to have experienced the greatest SOC increase (Zhang et al. 2007; Pan et al. 2010). In contrast, a lower level of crop residues, farm manure and green manure application enabled the southwest to emit least GHG in producing same amount of rice.

As to the GHGI of wheat production (Fig. 5b), all regions except north China exhibited the same trend as the national average. Consequently, reducing $\mathrm{N}$ rates should be advocated in northern provinces, confirming the findings of other experimental and theoretical studies (Ju et al. 2009, 2011). Maize GHGI evolution patterns (Fig. 5c) were more diverse between geographic regions, with northeast China having the lowest GHGI . The northwest has been characterized with the highest GHGI in both wheat and maize production. 


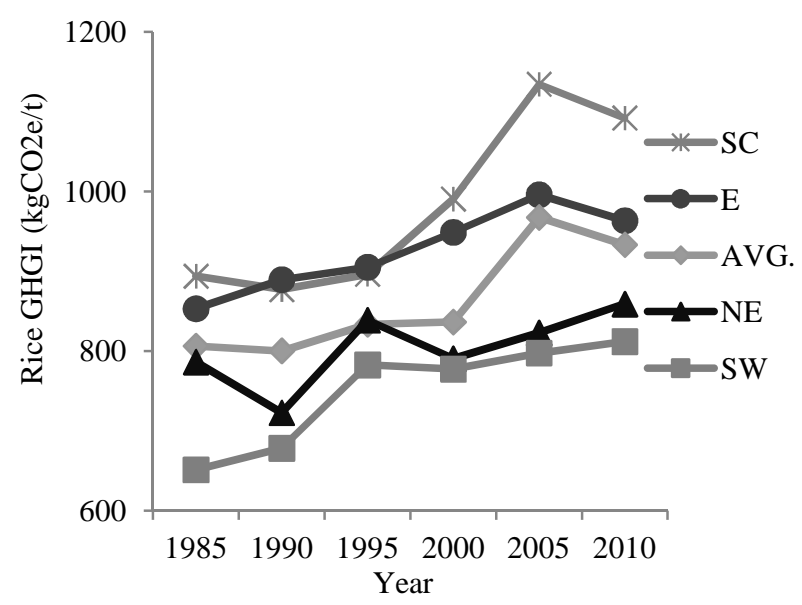

(a)

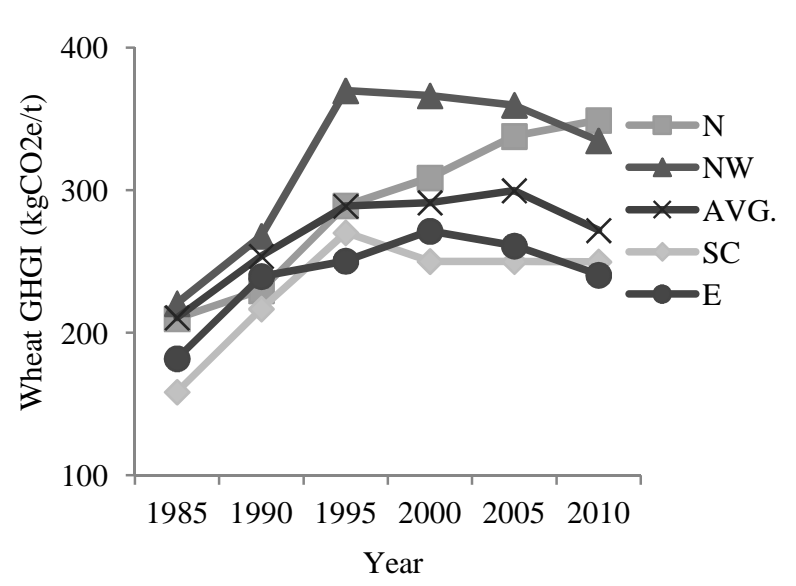

(b)

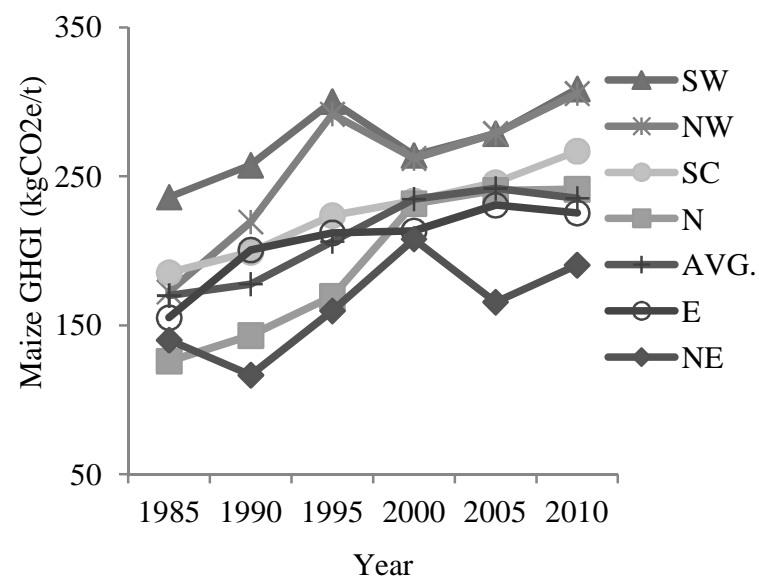

(c)

Fig.5. Historic evolution of regional GHGI of rice (a), wheat (b) and maize(c) production

3.5. Ways to improve GHGI of cereal production while safeguarding food security

Over the past 50 years, food production growth in China has been primarily driven by increasing yield per unit area rather than the expansion of cropping area. For example, from 1961 to 2010 there was an 8.5-fold increase in wheat productivity, with only a $30 \%$ increase in total cereal cropping area (FAO 2013). Ensuring food security in China in the future will still rely on yield improvement since rapid industrialization and urbanization will continue to encroach on China's arable land (UNDP 2013). Fan et al. (2012) argue that extension of existing technologies or better agricultural practices comprise the most effective near-term strategy for achieving higher resource (fertilizers and water) use efficiency, improving crop productivity and alleviating environmental impacts. In the longer term, continued 
genetic improvement through plant breeding will be crucial to ensure future food security.

Integrated soil-crop management systems and better nutrient management techniques are advocated to address the key constraints to yield improvement (Fan et al. 2012; Zhang et al. 2012a). Extensive overuse of synthetic $\mathrm{N}$ fertilizers is well documented in China (Chen et al. 2011; Cui et al. 2010), resulting in significant losses and serious environmental externalities (Guo et al. 2010). Zhang et al. (2013) suggest a possible $42 \%$ nationwide cut of $\mathrm{N}$ fertilizer use applying the balance concept to equalize $\mathrm{N}$ input and above ground $\mathrm{N}$ removal. In parallel to optimum quantity, application time, right placement and appropriate product are also essential to better nutrient management. Postponing $\mathrm{N}$ application to a later stage of crop growth and popularizing fertilizer deep placement by using appropriate machines for top-dressing could improve crop $\mathrm{N}$ uptake and minimize losses compared with conventional practices of applying large amount of $\mathrm{N}$ fertilizer on the surface before planting or at the early stages (Cui et al. 2008; Zhang et al. 2011b). Replacing a proportion of ammonium-based fertilizers with nitrate-based fertilizers in places where denitrification dominates $\mathrm{N}_{2} \mathrm{O}$ generation can help minimize $\mathrm{N}_{2} \mathrm{O}$ emissions and ammonia losses (Zhang et al. 2013). NUE can also be improved by applying fertilizers added with nitrification inhibitors (NI) and/or urease inhibitors (UI) and slow- and controlled-released fertilizers. Global meta-analysis results (Akiyama et al. 2010) suggest that NIs addition can lower $\mathrm{N}_{2} \mathrm{O}$ emission by $34 \%$ in upland fields and $30 \%$ in rice paddies on average, compared with those of conventional fertilizers.

Better recycling of organic manures including animal excreta, crop residues and green manure enables further improvement in NUE, SOC content and land productivity. Adopting conservation tillage is found to be conducive to accumulate SOC density, improve water availability and reduce water and wind erosion, especially on land of poor productivity (Xu et al. 2007; He et al. 2010). Such practices shall be extended to wider areas supported by the MOA (2009). Finally, biochar addition can be beneficial to soil quality and yield increase (Zhang et al. 2012b), therefore offering substantial mitigation potential when it becomes economically available. As to $\mathrm{CH}_{4}$ emissions from rice paddies, upgrading irrigation regimes from mid-season drainage (F-D-F), currently being practiced in most rice cultivation regions, to intermittent irrigation (F-D-F-M) or controlled irrigation, could avoid as much as $1.256 \mathrm{CO}_{2} \mathrm{e}$ per hectare according to nationwide meta-analysis results (Wang et al. 2014). 
Fig. 6 illustrates that total GHG emissions from rice, wheat and maize production have grown by $12 \%$ from 2005 to 2010 caused by an $11 \%$ increase in cropping area and a 5\% increase in average yield (Fig. $3 b)$. In the $\mathrm{S} 0$ baseline scenario, although yields improve at the same rate of increase in $\mathrm{N}$ inputs, resulting in constant GHGI, total GHG emissions will still go up because of higher production levels. However, if no more $\mathrm{N}$ input is needed to enhance yields, emissions will stop increasing (scenario $\mathrm{S} 1$ ) and GHGIs will decrease. In contrast, if better fertilization practices are promoted to suppress the overuse of $\mathrm{N}$ fertilizers, total emissions will decline (scenario S2) by $8 \%$ compared to S0. Scenario S3 assumes substantial efforts are dedicated to minimizing the GHGI of cereal production by eradicating $\mathrm{N}$ over-application, adopting better water management in rice paddies and improving yield levels. In this case, $\mathrm{I}_{\mathrm{N} 2 \mathrm{O}}$ of rice, wheat and maize shall decline by $2.5 \%, 3 \%$ and $3.4 \%$ respectively, and $\mathrm{I}_{\mathrm{CH} 4}$ by $1.5 \%$ annually. Under this scenario, total GHG emissions are estimated to be $224 \mathrm{MtCO}_{2} \mathrm{e}$, a $17 \%$ decrease relative to $\mathrm{S} 0$ enabled by an $18 \%$ decrease in $\mathrm{N}$ input, $0.5-1.5 \%$ improvement in yields and $1 \%$ cut in average $\mathrm{CH}_{4}$ flux. Such a mitigation scenario is feasible since the $18 \%$ cut in $\mathrm{N}$ use falls under the lower range of suggested 30-60\% reduction (Ju et al. 2012; Zhang et al. 2013) and the $546 \mathrm{Mt}$ cereal production meets the target for ensuring national food security.

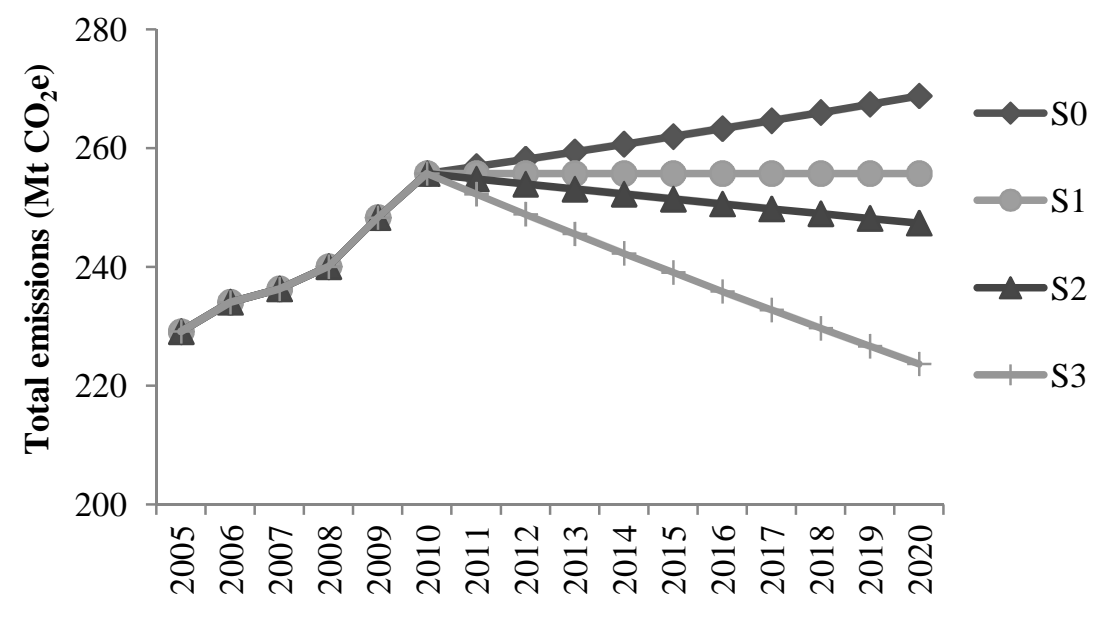

Year

Fig.6. GHG emission scenarios from rice, wheat and maize production to 2020 in China

Apart from the emission reduction potential, SOC density is projected to continue to increase at a rate of $0.4-0.48 \mathrm{tC} / \mathrm{ha} / \mathrm{yr}$ in paddy soils and 0.16-0.22 $\mathrm{tC} / \mathrm{ha} / \mathrm{yr}$ in upland soils in the $2010 \mathrm{~s}$ (Yu et al. 2013). This implies that even the $\mathrm{C}$ inputs (including manure and crop residue) to Chinese croplands remain unchanged with no improvement in tillage practices, aggregate national SOC stocks will still increase over the period 2010-2020. If improved agricultural management practices are widely adopted, 
394 as much as $70 \mathrm{MtCO}_{2}$ could be sequestrated in the cropland soils. Carbon sequestration is therefore 395 able to compensate $31 \%$ of GHG emissions under scenarios S3. 


\section{Conclusions}

A low carbon development pathway implies minimization of emissions while increasing food production and GHGI is an indicator combining both objectives. As such it is a central element of any definition of sustainable intensification (Godfray and Garnett 2104). Our results on the GHGI of rice, wheat and maize production show substantial heterogeneities among provinces/regions and indicate considerable scope for improving carbon performance of cereal production. Under the BAU scenarios where food production must grow to meet the demand of about 1.45 billion population, total GHG emissions will continue to increase albeit with constant GHGIs. Controlling GHG emissions from arable land thus requires additional mitigation efforts. Many abatement practices that improve crop yields will not only enable emission reductions but also improve soil fertility via carbon sequestration, therefore providing a triple win. Such findings can inform a broad range of policy, practitioner and investment discussions on GHG mitigation strategies, and can also serve as benchmark values for allocating quotas or as the baseline for generating carbon credits for any market-based mechanism.

Despite positive synergies with yield and soil fertility, abatement measures have not been widely adopted by farmers due to economic, political and social factors. Required capacity and infrastructure must be improved and agricultural extension service upgraded to lower GHGI and realize the mitigation potential and land productivity and fertility improvement potential that agricultural production offers.

\section{Acknowledgements}

416 This study is supported by the project "Integration and demonstration of key carbon sequestration and

417 mitigation technologies in the agricultural ecosystems" funded by the Chinese Ministry of Science and 418 Technology (2013BAD11B03) and the Research Initiative "Agriculture, Food, Forestry and Climate 419 Change" of the Climate Economics Chair of Paris-Dauphine University. 


\section{References}

Akiyama H, Yan XY, Yagi K (2010) Evaluation of effectiveness of enhanced-efficiency fertilizers as mitigation options for $\mathrm{N} 2 \mathrm{O}$ and $\mathrm{NO}$ emissions from agricultural soils: meta-analysis. Global Change Biology 16:1837-1846

Bonesmo H, Skjelvåg AO, Janzen HH, Klakegg O, Tveito OE (2012) Greenhouse gas emission intensities and economic efficiency in crop production: A systems analysis of 95 farms. Agricultural Systems 110:142-151

Chen XP, Cui ZL, Vitousek PM et al (2011). Integrated soil-crop system management for food security. Proc. Natl. Acad. Sci 108:6399-6404

Cui ZL, Zhang FS, Chen XP et al (2008) On-farm evaluation of an in-season nitrogen management strategy based on soil Nmin test. Field Crop Res. 105:48-55

Cui ZL, Chen XP, Zhang FS (2010) Current nitrogen management status and measures to improve the intensive wheat-maize system in China. Ambio 39:376-384

FAO (2013). FAOSTAT Database-Agriculture Production. http://faostat3.fao.org/home/, accessed June 2013

Gao LW, Ma L, Zhang WF et al (2009) Estimation of nutrient resource quantity of crop straw and its utilization situation in China. Transactions of the Chinese Society of Agricultural Engineering 25:173-179

Gao B, Ju XT, Zhang Q, Christie P, Zhang FS (2011) New estimates of direct N2O emissions from Chinese croplands from 1980 to 2007 using localized emission factors Biogeosciences Discussions 8:6971-7006

Godfray HCJ, Garnett T (2014) Food security and sustainable intensification. Phil Trans R Soc B. doi:101098/rstb20120273

Guo JH, Liu XJ, Zhang Y et al (2010) Significant acidification in major Chinese. croplands Science 327:1008-1010

Han LJ, Yan QJ, Liu XY, Hu JY (2002) Straw Resources and Their Utilization in China Transactions of the Chinese Society of Agricultural Engineering 18(3):87-91

He J, Li HW, Wang QJ et al (2010) The adoption of conservation tillage in China. Annals of the New York Academy of Sciences 1195:E96-E106

Heffer P (2009) Assessment of fertilizer use by crop at the global level. International Fertilizer Industry Association. http://sustainablecropnutritionnet/ifacontent/download/7204/113684/version/8/file/AgCom0928+ -+FUBC+assessment+at+the+global+level+(2006+\%2B+2007)pdf

Huang Y, Sun W (2006) Changes in topsoil organic carbon of croplands in mainland China over the last two decades. Chinese Science Bulletin 5:1785-1803

Huang Y, Tang Y (2010) An estimate of greenhouse gas (N2O and CO2) mitigation potential under various scenarios of nitrogen use efficiency in Chinese croplands. Global Change Biology 16:2958-2970 
Huang T, Gao B, Christie P, Ju XT (2013) Net global warming potential and greenhouse gas intensity in a double-cropping cereal rotation as affected by nitrogen and straw management. Biogeosciences 10:897-7911

IPCC (2006) IPCC Guidelines for National Greenhouse Gas Inventories IPCC/IGES. Hayama, Japan

IPCC (2007a) Food, fibre and forest products in Climate Change 2007: Impacts, Adaptation and Vulnerability, pp 273-313. Cambridge University Press, Cambridge, UK and New York, NY, USA

IPCC (2007b) Agriculture in: Climate Change 2007: Mitigation, pp 498-540. Cambridge University Press, Cambridge, UK and New York, NY, USA

Ju XT, Xing GX, Chen XP et al (2009) Reducing environmental risk by improving N management in intensive Chinese agricultural systems. Proc. Natl. Acad. Sci 106: 3041-3046

Ju XT, Christie P (2011) Calculation of theoretical nitrogen rate for simple nitrogen recommendations in intensive cropping systems: A case study on the North China Plain. Field Crops Research 124: $450-458$

Ma YC, Kong XW, Yang B et al (2013) Net global warming potential and greenhouse gas intensity of annual rice-wheat rotations with integrated soil-crop system management. Agriculture, Ecosystems \& Environment 164: 209-219

Ministry of Agriculture (MOA) (1986-2013) China Rural Statistical Yearbook. China Agricultural Press, Beijing

MOA (2001-2011) China Livestock Yearbook. China Agricultural Press, Beijing

MOA and Ministry of Finance (MOF) (2005) Notice on the issuance of "Interim management measures of subsidy funds for fertilizer recommendation pilots"

Mosier AR, Halvorson AD, Reule CA, Liu XJ (2006) Net global warming potential and greenhouse gas intensity in irrigated cropping systems in northeastern Colorado. J Environ Qual 35: 1584-1598

National Coordination Committee on Climate Change (NCCC) (2012) Second National Communication on Climate Change of the PRC. China Planning Press, Beijing

National Development and Reform Commission (NDRC) of China (2009) National Plan for Expansion of Grain Production Capacity by 50 million Mt during 2009-2020

NDRC (2006-2008) China Agricultural Products Cost-Benefit Yearbooks. China Statistics Press, Beijing

Norse D (2012) Low carbon agriculture: Objectives and policy pathways. Environmental Development $1: 25-39$

Oenema O, Velthof G, Kuikman P (2001) Technical and policy aspects of strategies to decrease greenhouse gas emissions from agriculture. Nutrient Cycling in Agroecosystems 60:301-315

Pan GX, Smith P, Pan W (2009) The role of soil organic matter in maintaining the productivity and yield stability of cereals in China. Agriculture, Ecosystems \& Environment 129: 344- 348

Pan GX, Xu X, Smith P, Pan W, Lal R (2010) An increase in topsoil SOC stock of China's croplands between 1985 and 2006 revealed by soil monitoring. Agriculture, Ecosystems \& Environment 136:133-138 
Shang Q, Yang X, Gao C, Wu P et al (2011) Net annual global warming potential and greenhouse gas intensity in Chinese double rice-cropping systems: a 3-year field measurement in long-term fertilizer experiments. Global Change Biology 17: 2196-2210

Smith P, Martino D, Cai Z et al (2008) Greenhouse gas mitigation in agriculture. PHILOS T ROY SOC B 363:789-813

State Administration of Grain (SAG) of the PRC (2013) Production prediction of major grain crops in 2013. http://wwwgrainnewscomcn/xw/news/gn/2013/10/15_197288html

Sun W, Huang Y, Zhang W, Yu Y (2010) Carbon sequestration and its potential in agricultural soils of China. Global Biogeoche mical Cycles 24(3):GB3001

Sun WJ, Huang Y (2012) Synthetic fertilizer management for China's cereal crops has reduced N2O emissions since the early 2000s. Environmental Pollution 160: 24-27

Tubiello FN, Salvatore M, Rossi S, Ferrara A (2012) Analysis of global emissions, carbon intensity and efficiency of food production. EAI research papers 4-5

Tubiello FN, Salvatore M, Cóndor Golec RD et al (2014) Agriculture, Forestry and Other Land Use Emissions by Sources and Removals by Sinks, 1990-2011 Analysis. FAO Working Paper Series ESS/14- 02

UNDP (2013) China Human Development Report 2013: Sustainable and Liveable Cities: Toward Ecological Urbanisation. China Publishing Group Corporation, Beijing

Van Groenigen JW, Velthof GL, Oenema O et al (2010) Towards an agronomic assessment of N2O emissions: a case study for arable crops. European Journal of Soil Science 6:903-913

Venterea RT, Maharjan B, Dolan MS (2011) Fertilizer source and tillage effects on yield-scaled nitrous oxide emissions in a corn cropping system. Journal of Environment Quality 40:1521-1531

Wang W, Koslowski F, Nayak DR et al (2014) Greenhouse gas mitigation in Chinese agriculture: distinguishing technical and economic potentials. Global Environmental Change. doi:1 0.1016/j.gloenvcha.2014.03.008

World Bank (2013) World Bank Data http://dataworldbankorg/. Accessed June 2013

Wreford AD, Moran D, Adger N (2010) Climate Change and Agriculture: Impacts, Adaptation and Mitigation. OECD Publishing

Xu Y, Chen W, Shen Q (2007) Soil Organic Carbon and Nitrogen Pools Impacted by Long-Term Tillage and Fertilization Practices. Communications in Soil Science and Plant Analysis 38:347-357

Yan XY, Cai ZC, Wang SW, Smith P (2011) Direct measurement of soil organic carbon content change in the croplands of China. Global Change Biology 17:1487-1496

Yu YQ, Huang Y, Zhang W (2012) Modeling soil organic carbon change in croplands of China, 1980-2009. Global and Planetary Change 82-83:115-128

Yu YQ, Huang Y, Zhang W (2013) Projected changes in soil organic carbon stocks of China's croplands under different agricultural managements, 2011-2050. Agriculture, Ecosystems \& Environment 178:109-120 
Zhang W, Yu YQ, Sun WJ, Huang Y (2007) Simulation of Soil Organic Carbon Dynamics in Chinese Rice Paddies from 1980 to 2000. Pedosphere 17:1-10

Zhang W, Yu Y, Huang Y, Li T, Wang P (2011a) Modeling methane emissions from irrigated rice cultivation in China from 1960 to 2050. Global Change Biology 17:3511-3523

Zhang FS, Cui ZL, Fan MS et al (2011b) Integrated soil-crop system management: Reducing environmental risk while increasing crop productivity and improving nutrient use efficiency in China. J Environ Qual 40:1-7

Zhang FS, Cui ZL, Chen XP et al (2012a) Integrated Nutrient Management for Food Security and Environmental Quality in China. In: Sparks, DL (ed) Advances in Agronomy 116, pp 1-40

Zhang AF, Liu Y, Pan GX et al (2012b) Effect of biochar amendment on maize yield and greenhouse gas emissions from a soil organic carbon poor calcareous loamy soil from Central China Plain. Plant and Soil 35:263-275

Zhang WF, Dou ZX, He P, et al (2013) New technologies reduce greenhouse gas emissions from nitrogenous fertilizer in China. Proc. Natl. Acad. Sci 110:8375-8380

Zheng XH, Fu CB, Xu XK et al (2002) The Asian nitrogen cycle case study. AMBIO 31:79-87 
This page is intentionally blank - Cette page est laissée vide intentionnellement 


\section{Working Paper Series}

$n^{\circ}$ 2014-09

$n^{\circ} 2014-09$

$n^{\circ}$ 2014-08
Greenhouse gas intensity of three main crops and implications for lowcarbon agriculture in China

Wen Wang, Yuebin Lin, Liping Guo, Yingchun Li, Man Su, Christian de Perthuis, Xiaotang Ju, Erda Lin, Dominic Moran

Fostering Renewables and Recycling a Carbon Tax: Joint Aggregate and Intergenerational Redistributive Effects

By Frédéric Gonand

Energy transition toward renewables and metal depletion: an approach through the EROI concept

By Florian Fizaine and Victor Court

$n^{\circ}$ 2014-06

Towards a clean vehicle fleet: from households' valuation of fuel efficiency to policy implications

By Bénédicte Meurisse and Maxime Le Roy

$n^{\circ} 2014-05$

The "Second Dividend" and the Demographic Structure

By Frédéric Gonand and Pierre-André Jouvet

\section{$n^{\circ} 2014-04$}

Interactions between $\mathrm{CO} 2$ and RES targets: A cost assessment of European Energy Climate Policies with POLES model

By Florent Le Strat, Elaine Pelourdeau, Benoît Peluchon, Jean-Yves Caneill, Yasmine Arsalane, and Kimon Keramidas

\section{$n^{\circ}$ 2014-03}

Social Acceptance and Optimal Pollution: CCS or Tax?

By Pierre-André Jouvet and Marie Renner

$n^{\circ}$ 2014-02

Carbon prices and CCS investment: comparative study between the European Union and China

By Marie Renner

Contact us :

Chaire Economie du Climat - Palais Brongniart (4e étage)

28 Place de la Bourse, 75002 Paris

Tel : +33 (0)173019331

Email : contact@chaireeconomieduclimat.org 